\title{
Vestigial teeth of the Pacific walrus Odobenus rosmarus divergens Illiger, 1815 (Carnivora: Odobenidae)
}

\author{
Natalia V. Kryukova
}

\begin{abstract}
Vestigial teeth of the Pacific walrus from the Chukotka Peninsula (Russia) were examined for 94 specimens. The following teeth were studied: the second upper and the third lower incisors, the fourth upper premolar, and the first upper and first lower molars. The upper second incisor is the largest among vestigial teeth and is less likely to be reabsorbed than the others. Growth duration for the majority of vestigial teeth is short (1-2 years). For most of the vestigial teeth, independent of the total number of cement layers and/or age of the walrus, only the enamel and partial upper part of dentine were worn off — without deforming any cementum layers. Generally the weight and width of the upper second incisor and the upper fourth premolar will increase relative to the number of annual cement layers added. For the majority of vestigial teeth examined, the number of cement layers coincided on pairs of teeth the same individual but seldom coincided with the number of cementum layers on other non-vestigial teeth. Because of irregular deposition of cementum layers, vestigial teeth should not be used for age determination of purposes.

How to cite this article: Kryukova N.V. 2018. Vestigial teeth of the Pacific walrus Odobenus rosmarus divergens Illiger, 1815 (Carnivora: Odobenidae) // Russian J. Theriol. Vol.17. No.2. P.78-84. doi: 10.15298/rusjtheriol.17.2.03
\end{abstract}

KEY WORDS: Pacific walrus, Odobenus rosmarus divergens, persistent deciduous teeth, rudimentary teeth, Pinnipeds, determination of age, morphology of teeth.

NataliaV. Kryukova [nkryukova@gmail.com] Russian Federal Research Institute of Fisheries and Oceanography (VNIRO), 17, Verkhnyaya Krasnosel'skaya Street, Moscow, 107140, Russia.

\section{Рудиментарные зубы тихоокеанского моржа Odobenus rosmarus divergens Illiger, 1815 (Carnivora: Odobenidae)}

\section{Н.В. Крюкова}

\begin{abstract}
РЕЗЮМЕ. Обследованы рудиментарные зубы тихоокеанского моржа Чукотского полуострова (Россия) - всего 94 особи. Были изучены следующие зубы: второй верхний и третий нижний резцы, четвертый верхний премоляр, первый верхний и первый нижний моляры. Второй верхний резец самый крупный среди рудиментарных зубов, менее остальных подвержен резорбции. Продолжительность роста в длину у большинства рудиментарных зубов небольшая (1-2 года). У большей части рудиментарных зубов независимо от общего числа слоев цемента и возраста животного стачивались только эмаль и частично верхняя выступающая часть дентина, не затрагивая слои цемента. Отмечалась общая тенденция увеличения веса и ширины верхнего второго резца и верхнего четвертого премоляра с увеличением количества слоев цемента на них. Чаще всего число слоев цемента на парах рудиментарных зубов от одного животного совпадало, но редко совпадало с числом слоев на функциональных зубах. Поскольку отложение слоев цемента нерегулярное на рудиментарных зубах, их нельзя использовать для определения истинного возраста животного.
\end{abstract}

КЛЮЧЕВЫЕ СЛОВА: тихоокеанский морж, Odobenus rosmarus divergens, рудиментарные зубы, ластоногие, определение возраста, морфология зубов.

\section{Introduction}

Existence of vestigial teeth is characteristic for different groups of mammals, such as: Lipotyphla, Lagomorpha, Chiroptera, Rodents, Tarsius, Carnivore, Artiodactyla, Perissodactyla, Pinnipeds, Cetacea (MossSalentijn, 1978; van der Merwe, 1997; Kuzin, 1999; Luckett, 1993; Miles \& Grigson, 1990; Nweeia et al., 2012; Drehmer et al., 2015). Vestigial teeth of mammals have atypical roots and usually don't erupt; they are either resorbed within the jaw or, rarely, shed into the oral cavity during the prenatal period (Luckett, 1993). In walruses, vestigial teeth regularly develop, and have alveolar and gingival eruption (Mansfield, 1958). Vestigial teeth differ externally from functional ones even during their alveolar eruption (Allen, 1880; Cobb, 1933) having smaller sizes, a small crown and a long root (Kryukova, 2012). They are poorly fixed in alveoli therefore part of them is lost in during the first year of life (Fay, 1982; Kryukova, 2012). However, 
some vestigial teeth remain in the jaw and occur in adult animals. As a result, there were many questions regarding the definition of a tooth formula for walruses. In one case the tooth formula was based on alveolar eruption, in another - on conserved of these teeth at adult individuals, and in the third - teeth used during feeding. Most authors provide two types of a tooth formula for walruses: 1) alveolar eruption of permanent teeth ( $\mathrm{I}^{3} / 3$, $\left.\mathrm{C}^{1} /{ }_{1}, \mathrm{Pm}^{4} /{ }_{3}, \mathrm{M}^{2} /=36\right)$, and 2$)$ functional teeth $\left(\mathrm{I}^{1 /}{ }_{0} \mathrm{C}\right.$ $1 / \mathrm{Pm}_{3}{ }_{3}=18$ ) (Allen, 1880; Cobb, 1933; Mansfield, 1958; Kryukova, 2012). Functional teeth are larger than vestigial teeth and bear the main load in the mechanics of feeding, and remain in the jaw for life. Its teeth usually use for walrus age determination (Mansfield, 1958; Krylov, 1965; Kryukova, 2014). Teeth which do not fit the formula of functional teeth, have been classed as vestigial. Vestigial as well as functional teeth regularly develop and can remain with adult animals. Vestigial teeth are of special interest regarding their use for age determination in walruses. The same works haven't been found in literature.

Our objective was to define the morphometric characteristics of vestigial teeth, investigate features of the layered deposition of dentine and cementum in these teeth, the extent of normal abrasion, and the use of vestigial teeth for age determination of walruses.

\section{Material and Methods}

Vestigial and functional teeth (except upper canines) from 94 dead or subsistence-harvested walruses were collected from the Bering and Chukchi seas and included: Retkyn Spit (Anadyr Gulf, Bering Sea) during 2007/2008, Kolyuchin Island (Chukchi Sea) during 2010, and Vankarem Cape (Chukchi Sea) during 2010/ 2011. Additionally, teeth were collected from dead walrus in the area of the Chegitun River (Chukchi Sea) during 2007. Sex of the animal was recorded when possible and included 11 males, 1 female, and 82 were undetermined. Vestigial teeth were extracted from walruses aged 5 years and older, without selection. A total 121 vestigial $\left(\mathrm{I}^{2}=70, \mathrm{Pm}^{4}=25, \mathrm{M}^{1}=2, \mathrm{I}_{3}=2, \mathrm{M}_{1}=7\right.$ and 15 unknown vestigial teeth) and 49 functional teeth were examined. A total of 21 walruses had functional and vestigial teeth simultaneously. Remain individuals had only vestigial teeth, of them 22 individuals had no less two vestigial teeth simultaneously. The collections of walrus tooth sections are stored in the Russian Federal Research Institute of Fisheries and Oceanography (VNIRO, Moscow, Russia).

The teeth were removed from the jaws, separated from any remaining tissues and weighed on an electronic scale $(0.001 \mathrm{~g})$. Using calipers, measurements of the total tooth length and maximum width were taken $(0.05$ $\mathrm{cm})$. Two longitudinal sections from the middle of each tooth with a thickness of 50-55 ìm (micrometer) were taken using a low-speed saw with a diamond coating (Buehler Isomet). One section was enclosed in permount for clearing of the layers and put under a cover- ing glass. A dry section and a cleared section were scanned using an Epson Perfection V700 Photo flatbed scanner to obtain high-resolution images (4000 dpi), for the best view of cementum layers. The photographs corresponded with the picture of sections in reflected light. Layers of cement and dentine were counted from the teeth images using contrast and sharpness features in Adobe Photoshop CS3 Software.

For walrus age determination we used standard methods, based on the layered structure of teeth (Klevezal, 1988; Kryukova, 2014). Every year single layer of dentine and single layer of cement are deposited on a walrus tooth. When the tooth pulp closed (at the age of 5 to 10 years), dentine stops but cement continues are depositing (Kryukova, 2017a). Age determination of walruses is based on counting cement layers deposited on a tooth root. A single cement layer consists of one light line and one dark line and corresponds one year of life (Mansfield, 1958). The dark cement layers were counted three times to determine age; the final age was calculated based on either the modal or mean value of the counts. For giving of subjectivity of results of age determination we used "index of layer readability" categories (Klevezal, 1988), where " 1 " is well-read layers, " 2 " is a difficult separation of layers making counts difficult, and " 3 " is layers unreadable. For the statistical treatment of data, we used the Statistica 8.0 package, one-way ANOVA (F), t-test (t), and Mann-Whitney U test (W).

We used the term "relative age" — age of walrus, was determined using the total number of cementum layers on the root walls of vestigial tooth, in other situation the terms "age" and "real age" — age of walrus was determined using the total number of cementum layers on the root walls of functional tooth.

\section{Results and discussion}

\section{Peculiarities of an external structure}

We examined vestigial teeth which had an alveolar eruption and remained in the walrus jaw. In the upper jaw were $\mathrm{I}^{2}, \mathrm{Pm}^{4}, \mathrm{M}^{1}$ and in the low jaw were $-\mathrm{I}_{3}, \mathrm{M}_{1}$.

In most cases $(84 \%)$ an $\mathrm{I}^{2}$ tooth externally differed in a curved shape and had a pointed top while other vestigial teeth had various shapes (Figs 1-3).

Morphometric data of vestigial teeth are provided below and do not include broken or strongly resorbed teeth (Tab. 1).

$\mathrm{I}^{2}$ teeth were significantly longer $(\mathrm{W}=2946.5, \mathrm{p}<$ $\left.0.001 ; \mathrm{t}=7.27, \mathrm{df}=79.92 ; \mathrm{F}_{(1,119)}=59.8\right)$ and heavier $\left(\mathrm{W}=2178, \mathrm{p}<0.01 ; \mathrm{t}=2.6984, \mathrm{df}=75.756 ; \mathrm{F}_{(1,115)}=\right.$ $8.36)$ than other vestigial teeth, however the width of $\mathrm{I}^{2}$ teeth remained small, similar to the others teeth (MannWhitney U test and One-way ANOVA didn't find significant differences). In rare cases, upper vestigial incisors $\left(\mathrm{I}^{2}\right)$ reached sizes of functional teeth (sizes of teeth are specified in Fay (1982), and Kryukova (2017a)). The maximum length of $\mathrm{I}^{2}$ teeth was $3.9 \mathrm{~cm}$, width was $1.45 \mathrm{~cm}$ and weight was $6.123 \mathrm{~g}$. However, the upper 


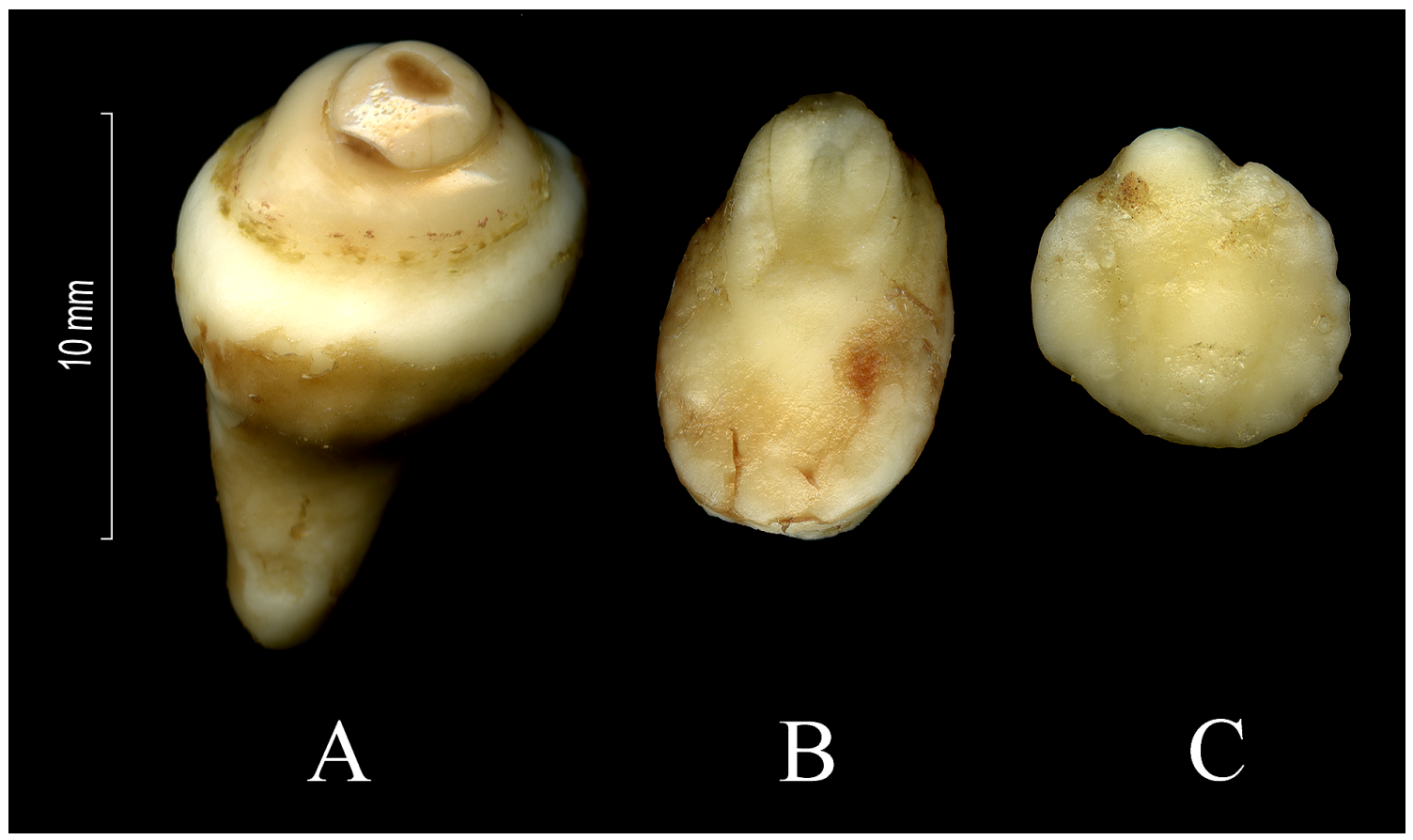

Fig. 1. Variants of vestigial teeth $\mathrm{Pm}^{4}$ in different Pacific walrus individuals: A — "relative age" 11 years, B "relative age" 11 years, $\mathrm{C}$ - "relative age" 10 years.

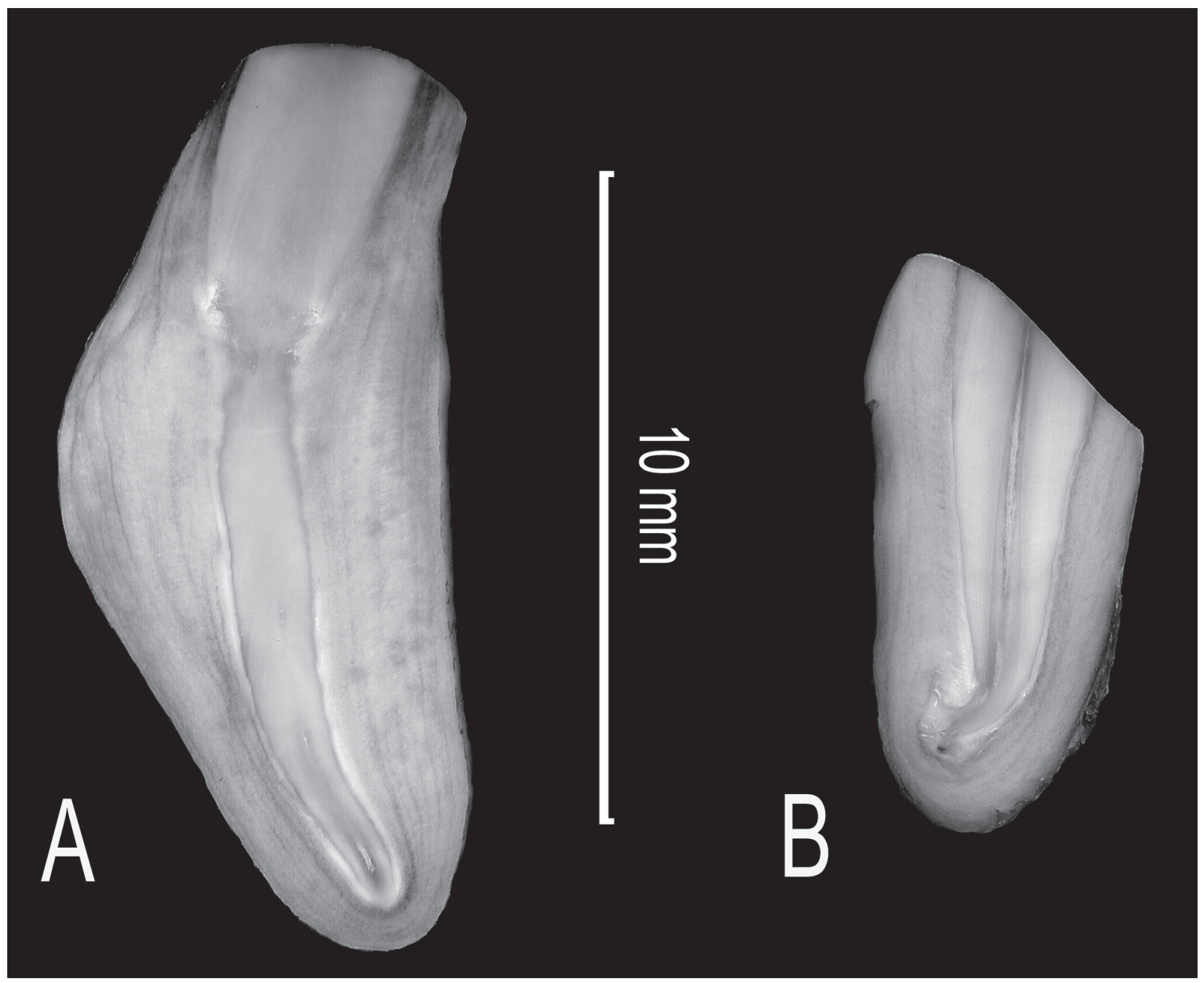

Fig. 2. Sections of low vestigial teeth in different individuals of the Pacific walrus: A — $\mathrm{I}_{3}$ "relative age" 7 years, B $M_{1}$ "relative age" 7 years. 


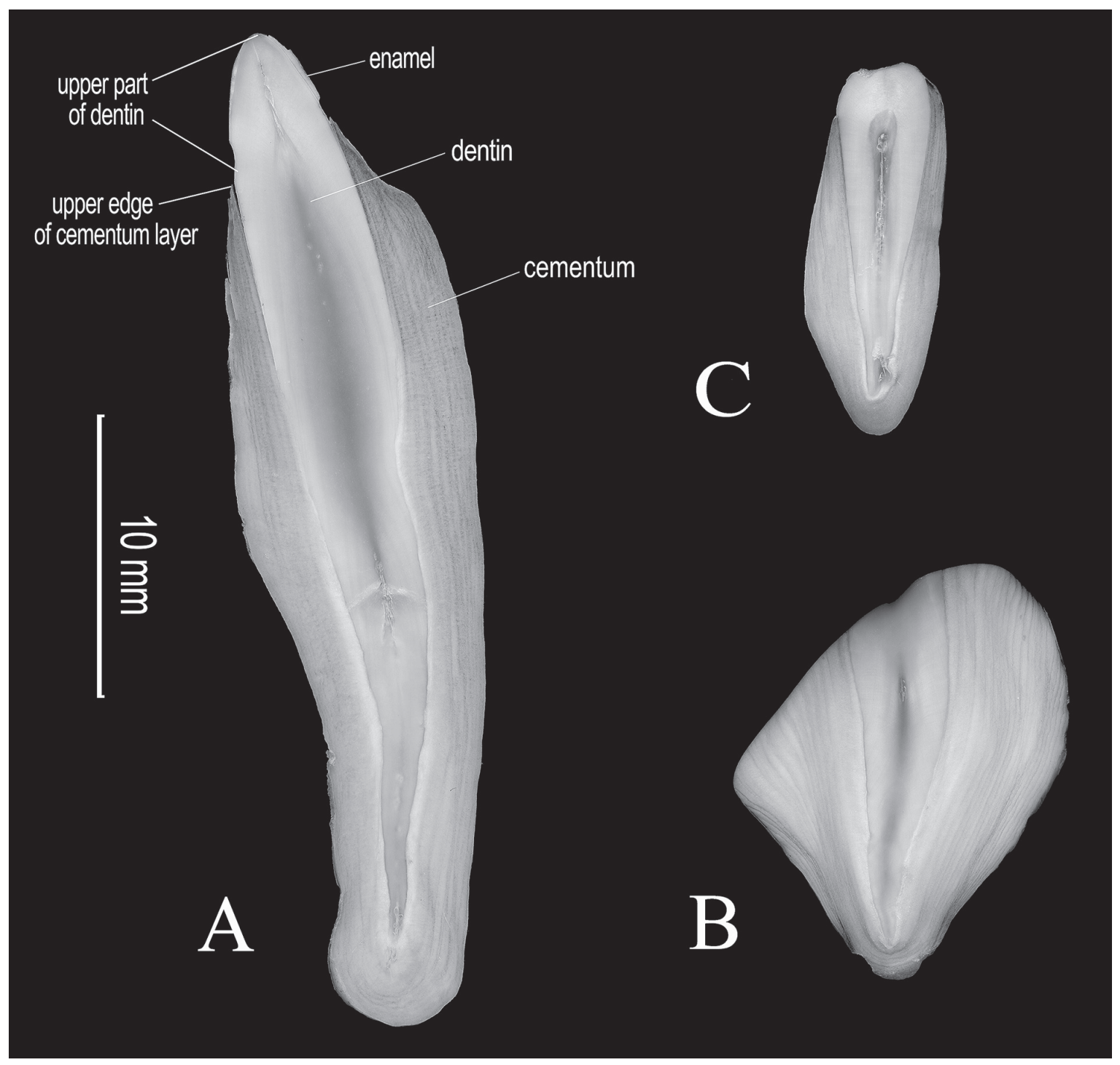

Fig. 3. Sections of upper vestigial teeth in different Pacific walrus individuals: A - $\mathrm{I}^{2}$ "relative age" 11 years, $\mathrm{B}-\mathrm{Pm}^{4}$ "relative age" 20 years, $\mathrm{C}-\mathrm{Pm}^{4}$ "relative age" 7 years.

part of this tooth was pointed - typical for this type of vestigial teeth (Fig. 3a). In this tooth the enamel was erased and the upper part of dentine was slightly abraded, probably the solid remains of the clamshells (food) slightly touched it. Thus, despite its large sizes, this vestigial tooth sat deeply in an alveolus and was not used during feeding events, unlike the functional teeth.

Weight and size of vestigial teeth displayed a wide variance of values (Tab. 1), and in some cases, young walruses had larger vestigial teeth than adults. Such cases are not rare, but we cann't specify the frequency of such meetings, since a large selection with functional and rudimentary teeth simultaneously is needed. We give an example of the maximum differences. A 7-year walrus (unknown sex) had a $\mathrm{Pm}^{4}$ tooth weighing 0.452 g, $1.35 \mathrm{~cm}$ length, and $0.7 \mathrm{~cm}$ width. This was 50.2 times heavier, 9 times longer and 2.3 times wider than the $\mathrm{Pm}^{4}$ tooth of a 15 -year-old male $(0.009 \mathrm{~g} ; 0.15 \mathrm{~cm}$ and $0.3 \mathrm{~cm}$, respectively). There were similarities for other teeth among individual walruses. For a 4-year walrus (unknown sex) values for the $\mathrm{I}^{2}$ tooth $(0.802 \mathrm{~g}$; 2.6 , and $0.6 \mathrm{~cm}$, respectively) were 2.9-3.7 times higher than for a 14-year-old male $(0.281 \mathrm{~g} ; 0.7 \mathrm{~cm}$, and 0.6 $\mathrm{cm}$, respectively). Meanwhile, the general tendency to enlargement of vestigial teeth with increase in number of cement layers at them have been traced. So, comparing $\mathrm{I}^{2}$ teeth between walrus groups with relative age 57 years old $(n=19)$ and relative age $16-20$ years old $(n=9)$ demonstrated that teeth of last group were significantly heavier $(\mathrm{F}=11.92, \mathrm{p}<0.01)$ and wider $\left(\mathrm{F}_{(1,26)}=31.62, \mathrm{p}<0.001\right)$ while the differences in tooth length were not significant (One-way ANOVA didn't find significant differences). The same situation was observed for $\mathrm{Pm}^{4}$ teeth when comparing two groups of walruses with relative age $7-10$ years old $(n=7)$ and relative age $19-26$ years old $(n=4)$. Adult walrus's 
Table 1. Morphometric data of $(n=99)$ vestigial teeth from the jaws of 94 walruses aged 5 year and older.

\begin{tabular}{|c|c|c|c|}
\hline Tooth & Weight, $\mathrm{g}$ & Length, cm & Width, cm \\
\hline $\mathrm{I}^{2}$ & $\begin{array}{c}1.279 \pm 1.006 \\
(\lim 0.127-6.123) \\
n=66\end{array}$ & $\begin{array}{c}2.343 \pm 0.753 \\
(\lim 0.7-3.9) \\
n=66\end{array}$ & $\begin{array}{c}0.81 \pm 0.219 \\
(\lim 0.4-1.45) \\
n=66\end{array}$ \\
\hline $\mathrm{Pm}^{4}$ & $\begin{array}{c}0.720 \pm 0.512 \\
(\lim 0.009-1.973) \\
n=21\end{array}$ & $\begin{array}{c}1.131 \pm 0.371 \\
(\lim 0.15-1.6) \\
n=24\end{array}$ & $\begin{array}{c}0.883 \pm 0.31 \\
(\lim 0.2-1.5) \\
n=23\end{array}$ \\
\hline $\mathrm{M}^{1}$ & - & $\begin{array}{c}0.6 \pm 0.1 \\
(\lim 0.5-0.7) \\
n=2\end{array}$ & $\begin{array}{c}0.525 \pm 0.025 \\
(\lim 0.5-0.55) \\
n=2\end{array}$ \\
\hline $\mathrm{I}_{3}$ & $\begin{array}{c}0.185 \pm 0.018 \\
(\lim 0.167-0.203) \\
n=2\end{array}$ & $\begin{array}{c}0.85 \pm 0.05 \\
(\lim 0.8-0.9) \\
n=2\end{array}$ & $\begin{array}{c}0.5 \pm 0 \\
(\lim 0.5-0.5) \\
n=2\end{array}$ \\
\hline $\mathrm{M}_{1}$ & $\begin{array}{c}0.251 \pm 0.169 \\
(\lim 0.046-0.501) \\
n=4\end{array}$ & $\begin{array}{c}1.05 \pm 0.241 \\
(\lim 0.8-1.4) \\
n=5\end{array}$ & $\begin{array}{c}0.488 \pm 0.147 \\
(\lim 0.25-0.65) \\
n=4\end{array}$ \\
\hline
\end{tabular}

teeth were significantly heavier $\left(\mathrm{F}_{(1,9)}=20.39, \mathrm{p}<0.01\right)$ and wider $\left(\mathrm{F}_{(1,9)}=18.17, \mathrm{p}<0.01\right)$ while no difference was detected for tooth length (One-way ANOVA didn't find significant differences) between age groups. For other vestigial teeth, sample sizes were insufficiently for the same comparison. Thus, the weight and width of vestigial teeth $\mathrm{I}^{2}$ and $\mathrm{Pm}^{4}$ increased with number of cement layers. At the same time, individual distinctions of vestigial teeth took place.

In rare instances, vestigial teeth (6 of 119 teeth) were so small they did not present gingival eruption but were detected by palpation under the gum. Expectedly, the unerupted teeth had no wear from abrasion.

\section{Peculiarities of an internal structure}

We investigated dentine of vestigial teeth to estimate the rate of growth (length). From entire samples of vestigial teeth $(n=119)$ we determined the number of dentine layers for 109 vestigial teeth. $32 \%$ of teeth had one dentine layer, $57 \%$ of teeth had two dentine layers, $9 \%$ of teeth had three dentine layers, $1 \%$ of teeth had four dentine layers, $1 \%$ of teeth had five dentine layers. Thus, most vestigial teeth grew in length up only the first two years, at the same time functional teeth grew in length up for to 10 years (Kryukova, 2014).

To understand how vestigial teeth are worn by abrasion we estimated extent of their abrasion using several parameters: enamel abrasion; abrasion of the upper part of dentine (Fig. 3a); cement abrasion.

We marked out the following extents of enamel abrasion: enamel unabraded; enamel with abrasion only on upper central part; and enamel completely removed. At 6 teeth from 119 (relative age of 7-17 years) enamel wasn't touched by abrasion, at 18 teeth (relative age of 2-25 years) enamel had been erased only in the central part, but its remains on a side part of a tooth top have remained, at other teeth (relative age of 4-35 years) enamel had been completely erased.

We estimated dentine abrasion using the following degrees: dentine unabraded; dentine was slightly abraded; dentine was partially erased; dentine was removed to the upper edge of the first deposit of cement layers. For $28 \%$ of teeth (relative age of 5-25 years) dentine had been slightly touched by abrasion, for $28 \%$ of teeth (relative age of 4-18 years) dentine had been partially erased, and for $31 \%$ of teeth (relative age of 5-35 years) the upper part of dentine had been erased to cement.

To determine the degree of cement abrasion we used the following degrees: cement unabraded; cement partially touched by abrasion; cement erased like in the plain erasing surface, all layers of cement removed evenly. The majority of teeth $(68 \%)$ had cement layers untouched by abrasion. For $16 \%$ of teeth (relative age of 10-12 years) cement layers were partially removed; for $16 \%$ of teeth (relative age of 8-26 years), there was touched by abrasion all layers of cement, and the plain erasing surface was formed. Thus, vestigial teeth were exposed little abrasion in comparison with functional teeth (Kryukova, 2014). Abrasion was primarily on enamel, partially on the dentine, and seldom on cementum layers. The degree of abrasion on a vestigial tooth was independent of relative age. Some young animals (relative age of 8 years) had the erased cement layers while at more adult individuals (relative age of 35 years) only the upper part of dentine was erased. The extent of tooth abrasion may depend on the depth of the tooth in the alveolus. Results confirm this fact as the largest vestigial tooth $\mathrm{I}^{2}$ (see above; $3.9 \mathrm{~cm}$ long) had only the upper part of dentine slightly touched by abrasion.

From 121 vestigial teeth - 18\% $(\mathrm{n}=22)$ had visually noticeable resorption of cement layers. This 
was typically observed in the lowest part of a root and the low part of root walls. One tooth $\left(\mathrm{Pm}^{4}\right)$ had eight new cement layers after resorption. The relative age of walruses having resorption traces on vestigial teeth very varied from 2 to 21 years. Resorption traces were more often noted on $\mathrm{M}^{1}$ ( 1 of 2$), \mathrm{M}_{1}$ ( 2 of 5), and at $\mathrm{Pm}^{4}$ (11 of 24$)$ than on $\mathrm{I}^{2}$ teeth (6 of 66$)$.

In contrast to functional teeth (Kryukova, 2017b), vestigial teeth did not exhibit dental disease. This likely is due to vestigial teeth not being directly in contact with food, other teeth, and do not bear a load during feeding.

\section{Determination of age}

By counting cement layers of 119 vestigial teeth, we estimated "index of layer readability" for cement layers: " 1 " in $57 \%$ of cases, " 2 " in $33 \%$ of cases, " 3 " in $10 \%$ of cases. Thus, the majority of vestigial teeth had readable cement layers.

When comparing the number of cement layers among different vestigial teeth from the same individual walruses (22 individuals, 46 teeth), we have found out that in $68 \%$ of cases their number has coincided. In $14 \%$ of cases, the number of layers differed with one layer; $9 \%$ the number differed with two layers; and $9 \%$ of cases differed with three and more layers. As most of the samples came from walruses that were dead in AugustOctober, during the formation of a new dark cement layer (Krylov, 1965) which we used for age assessment and in this time, it was thin and a so underestimation of age is possible. Therefore, the difference in one layer can be neglected. Thus, the majority $(82 \%)$ of vestigial teeth pairs for individual walruses had similar number of cement layers.

When comparing number of cement layers between vestigial and functional teeth from individual walruses ( 21 individuals, 81 teeth), $29 \%$ of individuals had the same the number of cement layers on the functional tooth and at least with one of vestigial teeth. At $19 \%$ of individuals their number differed with one layer, at $9 \%$ of individuals their number differed with two layers and at $43 \%$ of individuals with three and more layers. At the same time, the age of animals, which number of layers differed with three and more layers, age varied in the wide range from 5 to 26 years. Thus, deposition of cement layers on vestigial teeth is not related with the age of the walrus. Besides at all individuals in case of a divergence of number of cement layers on vestigial teeth their number was lesser than on functional teeth, and only at one individual on two vestigial teeth the number of cement layers was at 1-2 layers more than at functional teeth (readability of layers is " 1 ", age of 17 years)

We have estimated influence of "index of layer readability" of cement on a difference among number cement layers between vestigial and functional teeth of individual walruses. The majority of pairs of teeth $(88 \%)$ had a difference with two and more cement layers had index of layer readability " 1 ", and " 2 ", only two teeth had index " 3 ". Thus, to difference of number cement layers among teeth at one individual cannot influence the mistake related with bad readability of these.

It is possible that in certain cases, when the number of cement layers at a wall of a root of a vestigial tooth was less than on a wall of a root of a functional tooth it relates with strong resorption of the vestigial tooth (up to $1 / 2$ its estimated lengths). It is possible that during the resorption process new cement layers are not deposited on the tooth walls.

The maximum number of cement layers on a vestigial tooth was 35 layers, but unfortunately we did not have a functional tooth from this individual walrus for comparison. In total, 5 (6 teeth) of 94 walruses (119 teeth) had more than 20 cement layers. The majority of vestigial teeth $(86 \%)$ had 15 cement layers or less, $60 \%$ had 10 cement layers or less. Our average value of total number of cement layers at a tooth wall was $10.6 \pm 4.81$ layers (median was 9) $(n=119)$. This demonstrates the early slowdown of cement layers deposition on vestigial teeth. During growth of a walrus there is also active growth of its functional teeth (Kryukova, 2014). During growth of the walrus cement layers on vestigial teeth can regularly be deposited but after 10 years of age, when the walrus matures, the regularity of cement deposition sharply decreases. Though cement layers can be deposited on walls of a root of vestigial teeth throughout the life of a walrus, this process likely stops as the walrus matures.

\section{Conclusions}

Pacific walrus vestigial teeth were typically small in sizes and weight, though there is variability. The vestigial teeth, $\mathrm{I}^{2}$ and $\mathrm{Pm}^{4}$, at least, display tendency to increasing of the weight and width together with growth of the cement layers (relative age). The largest vestigial tooth is the upper second incisor, which is more often met at adult walruses. The majority of vestigial teeth grew in length only the first two years, were practically intact. Only enamel and partially most upper part of dentine was abraded. Some vestigial teeth had traces of resorption unrelated to the number of deposited cement layers on them. The upper second incisor is rarer than the other teeth was prostrated by resorption. Vestigial teeth had no defects by caries or any other dental disease. The majority of vestigial teeth had easily readable cement layers. When comparing the number of layers on of vestigial teeth pairs from individual walruses, there was more often coincidence while when comparing number of layers between vestigial and functional teeth divergences had been more. Besides, the greatest numbers of vestigial teeth with number of cement layers 15 or less was noted, we can conclude the early slowdown of cement deposition on teeth. Therefore, despite good preservation of vestigial teeth they should not be used to determine walrus age.

Acknowledgements. The author is very grateful to the Laboratory of Postnatal Ontogenesis, Koltzov Insti- 
tute of Developmental Biology, RAS, for the research opportunity, G.A. Klevezal for the maintenance of my work and comprehensive assistance at various stages of its implementation, as well as D.D. Vasyukov (Severtsov Institute of Ecology and Evolution, RAS) for the material provided from the Chegitun River area. Thanks a lot of G. Sheffield for the valuable help in editing article. Additionally, we thank the hunters that allowed their harvest to be sampled. We are also sincerely grateful to Prof. Alexander V. Borodin for their valuable comments to the manuscript.

\section{References}

Allen J.A. 1880. History of North American pinnipeds. A monograph of the walruses, sea lions, sea bears and seals of North America. Washington: Government printing office. $773 \mathrm{p}$.

Cobb W.M. 1933. The dentition of the walrus (Odobenus obesus) // Proceedings of the Zoological Society of London. Vol.103. No.3. P.645-668.

Drehmer C.J., Sanfelice D. \& Loch C. 2015. Dental anomalies in pinnipeds (Carnivora: Otariidae and Phocidae): occurrence and evolutionary implications // Zoomorphology. Vol.134. No.2. P.325-338.

Fay F.H. 1982. Ecology and biology of the pacific walrus, Odobenus rosmarus divergens, Illiger // North American Fauna. Vol.74. Washington, D.C.: US Department of the Interior, Fish and Wildlife Service. 279 p.

Klevezal G.A. 1988. [Recording structures of mammals in zoological studies]. Moscow: Nauka. 283 p. [In Russian]

Krylov V.I. 1965. [Determination of age, growth rate and age structure of the Pacific walrus population] // Pavlovskii E.N., Zenkovich B.A., Kleinenberg S.E., Chapskii K.K. (eds.). Morskie mlekopitayushchie. Moscow: Nauka. P.201-211 [in Russian].

Kryukova N.V. 2012. Dentition in Pacific walrus (Odobenus rosmarus divergens) calves of the year // Biology Bulletin. Vol.39. No.7. P.618-626.
Kryukova N.V. 2014. The method of age determination of the Pacific walrus (Odobenus rosmarus divergens) using the layered structure of functional teeth // Biology Bulletin. Vol.41. No.8. P.681-689.

Kryukova N.V. 2017a. Age-related changes in functional teeth in the Pacific walrus (Odobenus rosmarus divergens) // Biology Bulletin. Vol.44. No.7. P.820-825.

Kryukova N.V. 2017b. Caries in teeth of the Pacific walrus // Abstract book. 22 ${ }^{\text {nd }}$ Biennial conference on the Biology of Marine Mammals (Halifax, Nova Scotia, Canada, October 22-27). Halifax. P.217.

Kuzin A.E. 1999. [Northern fur seal]. Moscow: Marine Mammal Council. 395 p. [In Russian]

Luckett W.P. 1993. An ontogenetic assessment of dental homologies in Therian Mammals // Szalay F.S. Novacek M.J., McKenna M.C. (eds.). Mammal Phylogeny. New York: Springer Science+Business Media. P.182-203.

Mansfield A.W. 1958. The biology of the Atlantic walrus, Odobenus rosmarus rosmarus (Linnaeus) in the eastern Canadian Arctic // Fisheries Research Board Canada Manuscript Report Series (Biology). No.653. 146 p.

van der Merwe M. 1997. Vestigial teeth in the genus Scotoecus (Mammalia: Chiroptera): adapted dental formulae for vespertilionids with vestigial teeth // South African Journal of Zoology. Vol.32. No.3. P.76-81.

Miles A.E.W. \& Grigson C. 1990. Colyer's variations and diseases of the teeth of animals. Revised edition. Cambridge: Cambridge University Press. 676 pp.

Moss-Salentijn L. 1978. Vestigial teeth in the rabbit, rat and mouse; their relationship to the problem of lacteal dentitions // Butler P.M., Joysey K.A. (eds.). Development, Function and Evolution of Teeth. London: Academic Press. P.13-29.

Nweeia M.T., Eichmiller F.C., Hauschka P.V., Tyler E., Mead J. G., Potter C.W., Angnatsiak D.P., Richard P.R., Orr J.R. \& Black S.R. 2012. Vestigial tooth anatomy and tusk nomenclature for Monodon monoceros // The Anatomical Record Vol.295. No.6. P.1006-1016. 